\begin{tabular}{ll}
\hline Thabiea : Journal of Natural Science Teaching \\
Program Studi Tadris Ilmu Pengetahuan Alam \\
Institut Agama Islam Negeri Kudus \\
http://journal.stainkudus.ac.id/index.php/Thabiea \\
$p$-issn: 25808474
\end{tabular}

\title{
Pengembangan Petunjuk Praktikum IPA Fisika-Kimia Berbasis Learning Cycle 5E untuk Meningkatkan Keterampilan Proses Sains Calon Guru MI/SD
}

\author{
Zuanita Adriyani ${ }^{\mathrm{a}, 1}$, Kristi Liani Purwanti ${ }^{\mathrm{a}, 2}$ \\ ${ }^{a}$ UIN Walisongo Semarang \\ ${ }^{1}$ zuanita.adriyani@walisongo.ac.id; ${ }^{2}$ kristi_liani@walisongo.ac.id
}

\begin{tabular}{ll}
\hline Kata kunci: & ABSTRAK \\
\hline Petunjuk & Penelitian ini bertujuan untuk mengembangkan petunjuk praktikum IPA Fisika- \\
praktikum & Kimia berbasis learning cycle 5E yang valid dan implementasi petunjuk praktikum \\
IPA Fisika- & IPA Fisika-Kimia tersebut diharapkan dapat meningkatkan keterampilan Proses \\
Kimia, & Sains Calon guru. Prosedur pengembangan dalam penelitian ini mengadopsi berbasis \\
Model & pengembangan Cennamo dan Kalk dengan langkah - langkah (1) fase pendefinisian \\
Pembelajaran & yang meliputi studi pustaka, observasi awal; (2) fase perencanaan petunjuk \\
Learning & praktikum IPA Fisika-Kimia dan instrumen penelitian; (3) fase peragaan atau uji \\
Cycle 5E, & coba skala kecil; (4) fase pengembangan petunjuk praktikum IPA Fisika-Kimia; dan \\
Keterampilan & (5) fase penyajian pada skala luas. Desain penelitian yang digunakan adalah "one \\
Proses Sains & group pretest posttest design". Pengambilan sampel dilakukan dengan teknik \\
& purposive sampling. Populasi sample yang terpilih adalah mahasiswa Pendidikan \\
& Guru Madrasah ibtidaiyah (PGMI) UIN Walisongo Semarang semester IV angkatan \\
& 2016/2017. Hasil simpulan bahwa Petunjuk praktikum IPA Fisika-Kimia yang \\
dikembangkan memenuhi kriteria sangat valid. Petunjuk praktikum IPA Fisika- & Kimia yang dikembangkan dapat meningkatkan keterampilan proses sains calon guru \\
& MI/SD dengan nilai N-gain sebesar 0,51 dengan kategori sedang. Respon mahasiswa \\
& terhadap petunjuk praktikum IPA Fisika-Kimia yang dikembangkan adalah sangat \\
baik dengan rerata skor 26,6.
\end{tabular}

\begin{tabular}{ll}
\hline Keywords: & ABSTRACT \\
\hline $\begin{array}{l}\text { Instructions on } \\
\text { Physics-Chemistry }\end{array}$ & $\begin{array}{l}\text { This study aims to develop a valid 5E learning cycle based on Physics-Chemistry } \\
\text { practicum instructions and the implementation of the Physics-Chemistry Science }\end{array}$ \\
5E Learning Cycle & Science practicum guidance is expected to improve the skills of prospective Teacher \\
Learning Model, & Science Processes. The development procedure in this study adopts the development \\
of Cennamo and Kalk with steps (1) the defining phase which includes literature \\
Science Process
\end{tabular}$\quad \begin{aligned} & \text { study, initial observation; (2) the planning phase of the Physics-Chemistry practicum } \\
& \text { instructions and research instruments; (3) small scale demonstration or trial phase; } \\
& \text { (4) phase of development of Physics-Chemistry science practicum instructions; and } \\
& \text { (5) the presentation phase on a broad scale. The research design used was "one group } \\
& \text { pretest posttest design". Sampling is done by purposive sampling technique. The } \\
& \text { sample population selected was students of Madrasah Ibtidaiyah Teacher Education } \\
& \text { (PGMI) UIN Walisongo Semarang in semester IV of the 2016/2017 class. The } \\
& \text { conclusion that the developed Physics-Chemistry Science practicum instructions } \\
& \text { meet the criteria are very valid. The developed Physics-Chemistry Science practicum } \\
& \text { instructions can improve science process skills of MI / SD teacher candidates with } \\
& \text { an N-gain value of 0.51 with a moderate category. Student responses to the developed } \\
& \text { Physics-Chemistry Science practicum instructions were very good with a mean score } \\
& \text { of 26.6. }\end{aligned}$

Copyright (C) 2018 Institut Agama Islam Negeri Kudus. All Right Reserved 


\section{Pendahuluan}

Sains pada hakekatnya tidak hanya menyangkut hasil atau produk saja melainkan juga proses. Proses pembelajaran sains menekankan pada pemberian pengalaman langsung untuk mengembangkan kompetensi agar menjelajahi dan memahami alam sekitar secara ilmiah karena sains diperlukan dalam kehidupan sehari-hari. Adisendjaja (2009) mengatakan bahwa guru ketika membelajarkan sains harus memperhatikan dua hal yaitu hakekat bagaimana siswa belajar dan hakekat materi yang diajarkan. Guru professional abad 21 yaitu guru yang memiliki kepribadian matang, menguasai ilmu pengetahuan dan tekhnologi, menguasai keterampilan membangkitkan minat dan potensi yang berkesinambungan (H. A. R Tilaar dalam Hendri: 2010). Guru sains yang profesional juga harus mengembangkan kemampuannya sehingga dapat mengajar sesuai dengan tuntutan kurikulum. Kurikulum yang diberlakukan di sekolah saat ini menuntut adanya peran aktif siswa dalam menemukan konsep materi yang sedang dipelajari. Oleh karena itu, guru sains harus dapat menciptakan suasana yang dapat mendukung kegiatan tersebut.

Fakultas Ilmu Tarbiyah dan Keguruan UIN Walisongo khususnya prodi PGMI sebagai ranah mencetak guru MI/SD yang professional berusaha untuk menyediakan sarana dan prasarana yang dapat membentuk guru yang berketerampilan. Keterampilan yang dimaksud salah satunya adalah keterampilan proses sains dalam melakukan praktikum IPA. Keterampilan proses sains merupakan sebuah pendekatan yang didasarkan pada pengujian dari apa yang biasa para ilmuwan lakukan (Sapriati, dkk,: 2011). Peserta didik belajar seperti layaknya para ilmuwan seperti mengobservasi, mengukur, mengklasifikasi, berkomunikasi, dll. Dalam belajar peserta didik menggunakan pikirannya untuk menemukan suatu konsep melalui sebuah diskusi kecil dengan melibatkan alat dan bahan serta alat indra. Hal ini selaras dengan pernyataan dari
Rustaman (2005) bahwa keterampilan proses melibatkan keterampilan-keterampilan kognitif atau intelektual, manual dan sosial. Keterampilan kognitif terlibat karena peserta didik menggunakan pikirannya dalam menemukan konsep materi yang sedang dipelajari. Keterampilan manual juga terlibat karena dalam mendapatkan konsep materi tersebut, peserta didik diajak secara langsung dalam menemukan konsep mungkin dengan menggunakan alat dan bahan, melakukan pengukuran, penyusunan atau perakitan alat. Sedangkan keterampilan sosial dimaksudkan bahwa peserta didik dalam menemukan konsep tersebut saling berinteraksi dengan sesamanya seperti mendiskusikan hasil pengamatan. Keterampilan proses terdiri atas sejumlah keterampilan yang satu sama lain sebenarnya tak dapat dipisahkan diantaranya: 1) Melakukan pengamatan (observasi), 2) Menafsirkan pengamatan (interpretasi), 3) Mengelompokkan (klasifikasi), 4) Meramalkan (prediksi), 5) Berkomunikasi, 6) Berhipotesis, 7) Merencanakan percobaan atau penyelidikan, 8) Menerapkan konsep dan prinsip, dan 9) Mengajukan pertanyaan (Rustaman: 2005). Sementara menurut Sapriati (2011) bahwa keterampilan proses sains terbagi menjadi dua bagian yaitu keterampilan proses dasar dan terpadu.

Kemampuan mahasiswa dalam menguasai keterampilan proses sains perlu diukur oleh dosen sebagai acuan untuk meningkatkan kualitas pembelajaran dan evaluasi pembelajaran. Hal ini sejalan dengan pernyataan Trianto (2013) bahwa keterampilan proses perlu dilatih dan dikembangkan dalam pengajaran IPA karena keterampilan proses mempunyai peranan yang sangat penting diantaranya : (1) Membantu mahasiswa belajar mengembangkan pikirannya, (2) Memberi kesempatan kepada mahasiswa untuk melakukan penemuan, (3) Meningkatkan daya ingat, (4) Memberi kesempatan kepuasan instrinsik bila telah berhasil melakukan sesuatu, (5) Membantu mahasiwa mempelajari konsepkonsep sains. 
Perangkat pembelajaran merupakan suatu pegangan bagi guru atau dosen dalam proses pembelajaran baik di kelas maupun laboratorium. Suatu perangkat pembelajaran terutama dalam pembelajaran IPA, harus dapat memfokuskan pada pemberian pengalaman secara langsung kepada mahasiswa dalam memanfaatkan dan menerapkan konsep, prinsip dan fakta sains melalui suatu pengamatan atau penyelidikan. Mata kuliah praktikum IPA II MI/SD (Fisika-Kimia) merupakan mata kuliah wajib bagi mahasiswa PGMI UIN Walisongo Semarang setelah mendapatkan mata kuliah konsep dasar IPA Fisika-Kimia. Kegiatan praktikum IPA yang selama ini dilakukan di Jurusan PGMI FITK UIN Walisongo masih menggunakan buku petunjuk praktikum IPA yang konvensional hanya berisi petunjukpetunjuk yang harus dikerjakan mahasiswa. Berdasarkan hasil angket dari mahasiswa jurusan PGMI Fakultas Ilmu Tarbiyah dan Keguruan semester tiga angkatan tahun 2016/2017 tentang buku petunjuk praktikum yang digunakan serta proses pembelajarannya didapatkan hasil sebagai berikut: 1) Buku petunjuk praktikum dirasa kurang menarik sehingga kurang berminat untuk membacanya, 2) Bahasa pada buku petunjuk praktikum susah dipahami dan berbelit-belit, 3) Alat, bahan dan cara kerja kurang sinkron sehingga membingungkan, 4) Daftar pertanyaan kurang memacu untuk berpikir mahasiswa dan 5) Seluruh mahasiswa sepakat untuk mengaitkan konsep materi dengan kehidupan sehari-hari. Kegiatan praktikum dilakukan seperti biasa yaitu mahasiswa disibukkan untuk mengerjakan praktek sama dengan langkah kerja yang ada di petunjuk praktikum, belum nampak adanya variasi pembelajaran sehingga mahasiswa terlihat kurang bersemangat dalam mengikuti pembelajaran. Keterampilan proses sains belum teramati, selama ini masih mengutamakan hasil saja. Dari hasil observasi awal tersebut peneliti hendak melakukan perbaikan dalam bentuk pengembangan terhadap petunjuk praktikum yang ada.
Zulyetti (2012) menyatakan bahwa penuntun praktikum ditujukan untuk membantu dan menuntun siswa agar dapat bekerja secara kontinu dan terarah. Oleh karena itu perlu dikembangkan perangkat pembelajaran berupa buku petunjuk praktikum yang mampu mengembangkan dan mengaktifkan mahasiswa untuk melakukan praktikum sehingga mampu mengoptimalkan keterampilan proses sains mahasiswa. Selain itu, kami sebagai pengajar belum mengajak secara maksimal dalam mengaitkan konsep yang dipelajari ke fenomena nyata. Peneliti dapat mengembangkan buku petunjuk praktikum IPA yang sudah ada dengan berbasis pada salah satu berbasis pembelajaran dengan harapan dapat mewujudkan keteraturan dalam belajar dan berpusat pada mahasiswa, sehingga mahasiswa aktif dalam mengkonstruksi pengetahuan agar lebih bermakna. Salah satu model pembelajaran yang dapat diterapkan dalam kegiatan praktikum adalah model learning cycle 5E. Simatupang (2008) menjelaskan bahwa learning cycle adalah suatu siklus belajar yang terdiri dari rangkaian tahap-tahap kegiatan yang diorganisasikan sedemikian rupa melalui peran aktivitas siswa sehingga tujuan pembelajaran dapat tercapai secara efektif dan efisien sebab learning cycle merupakan model pembelajaran yang berpusat pada siswa, sehingga menemukan sendiri pengetahuannya. Model pembelajaran siklus belajar mudah dipelajari dan sangat bermanfaat dalam menciptakan kesempatan dalam belajar sains dan model pembelajaran yang didasarkan pada penyelidikan (Lorsbach dan Walbert dalam Permatasari, dkk: 2016). Penelitian serupa juga dilakukan oleh Hasret et all (2006) yang menyimpulkan bahwa model learning cycle yang diterapkan pada kegiatan praktikum dapat meningkatkan hasil belajar siswa. Berdasarkan latar belakang di atas, mengingat hasil observasi awal dan pentingnya penguasaan keterampilan proses sains oleh calon guru MI/SD ketika mengajarkan sains serta telah banyaknya keberhasilan keterlaksanaan model pembelajaran learning cycle 5E, maka peneliti 
hendak melakukan pengembangan pada petunjuk praktikum IPA yang ada dengan berbasis pada model pembelajaran tersebut.

\section{Metode}

Jenis penelitian ini adalah penelitian pengembangan (development research), yaitu pengembangan petunjuk praktikum IPA FisikaKimia berbasis learning cycle 5E yang memenuhi kriteria valid pada praktikum IPA II. Pengembangan difokuskan pada petunjuk praktikum yang dapat meningkatkan keterampilan proses sains calon guru MI/SD pada percobaan kalor.

Model pengembangan memodifikasi model pengembangan pendidikan umum Cennamo dan Kalk (2005). Model pengembangan petunjuk praktikum dalam penelitian ini terdiri atas: (1) Define phase (pendefinisian)yang meliputi studi pustaka dan observasi awal; (2) Design phase (perencanaan) yaitu perencanaan pembuatan petunjuk praktikum IPA Fisika-Kimia berbasis learning cycle 5E dan instrumen penelitian, (3) Demonstrate phase (peragaan) yaitu proses uji coba pada skala kecil; (4) Develop phase (pengembangan) yaitu tahap perbaikan petunjuk praktikum setelah diimplementasikan dalam skala kecil, (5) Deliver phase (penyajian) dalam skala luas.

Skema alur pengembangan petunjuk praktikum menurut Cennamo dan Kalk dapat ditunjukkan seperti pada Gambar 1.

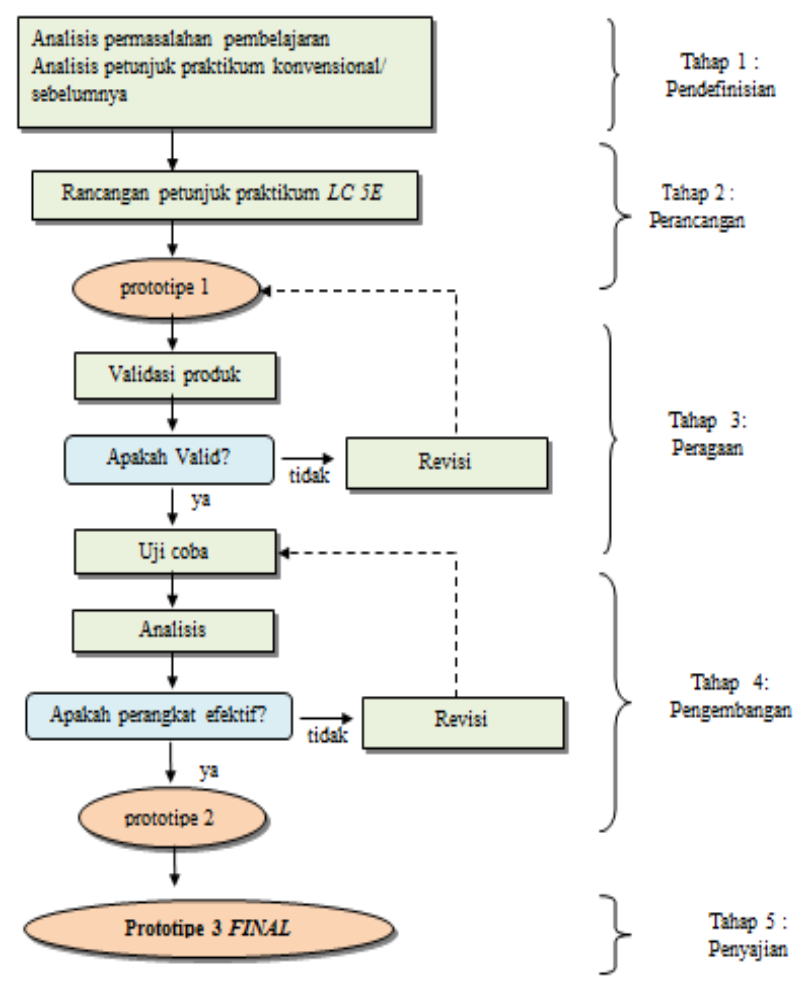

Gambar 1. Skema Alur Pengembangan Petunjuk praktikum Berbasis Cennamo dan Kalk (2005)

\section{Hasil dan Pembahasan}

Penelitian dilaksanakan pada bulan April sampai dengan bulan Juni tahun 2018 di jurusan PGMI UIN Walisongo Semarang dengan subyek penelitian 1 kelas yaitu kelas 4A-(2) dengan teknik pengambilan sample purposive sampling.

\section{Hasil Tahap Pendefinisian (Define Phase)}

\section{Studi Literatur}

Pada tahap awal penelitian ini dilakukan studi pendahuluan yang terdiri dari studi literatur dan observasi awal. Studi literatur dilakukan terhadap hasil penelitian sebelumnya baik yang dilakukan di dalam atau diluar negeri yang berhubungan dengan pembelajaran berbasis learning cycle $5 \mathrm{E}$ dan keterampilan proses sains. Sedangkan observasi awal dilakukan peneliti dengan memberikan angket kepada mahasiswa PGMI kelas 4A angkatan tahun 2016/2017 sejumlah 41 mahasiswa. 
Observasi Awal

Hasil observasi awal menunjukkan bahwa Berdasarkan hasil angket dari 41 mahasiswa jurusan PGMI Fakultas Ilmu Tarbiyah dan Keguruan semester tiga angkatan tahun 2016/2017 tentang buku petunjuk praktikum yang digunakan serta proses pembelajarannya didapatkan hasil sebagai berikut:

a. 27 mahasiswa menyatakan buku petunjuk praktikum dirasa kurang menarik sehingga kurang minat untuk membacanya,

b. 36 mahasiswa menyatakan bahwa bahasa pada buku petunjuk praktikum susah dipahami dan berbelit-belit,

c. 23 mahasiswa menyatakan alat, bahan dan cara kerja kurang sinkron sehingga membingungkan,

d. 16 mahasiswa menyatakan daftar pertanyaan kurang memacu untuk berpikir mahasiswa.

e. 41 mahasiswa sepakat menyatakan bahwa perlunya mengaitkan konsep materi dengan kehidupan sehari-hari

\section{Hasil Tahap Perencanaan (Design Phase)}

Hasil Validasi Petunjuk Praktikum

Petunjuk Praktikum yang sudah dirancang kemudian divalidasi oleh dua tim ahli (validator). Validator yang dilibatkan pada validasi petunjuk praktikum adalah empat dosen ahli yaitu dua dosen sebagai ahli materi dan dua dosen sebagai ahli media. Berdasarkan hasil validasi konstruk, petunjuk praktikum berbasis learning cycle 5E memenuhi kriteria sangat valid dan dapat digunakan namun perlu revisi kecil. Hasil validasi oleh tim ahli dapat dilihat pada Tabel 1.

\begin{tabular}{lcc}
\multicolumn{3}{c}{ Tabel 1. Hasil Analisis Validasi Ahli } \\
\hline No & $\begin{array}{c}\text { Nilai } \\
\text { Validator Ahli } \\
\text { Materi }\end{array}$ & $\begin{array}{c}\text { Nilai } \\
\text { Validator } \\
\text { Ahli Media }\end{array}$ \\
\hline \multicolumn{1}{c}{1} & 65 & 46 \\
2 & 67 & 46 \\
Rata-rata & 66 & 46 \\
Rata-rata & \multicolumn{2}{c}{56} \\
Total & \multicolumn{2}{c}{ Sangat Valid } \\
Kriteria & \multicolumn{2}{c}{} \\
\hline
\end{tabular}

Petunjuk praktikum yang telah dikembangkan perlu adanya revisi kecil atas saran dari validator ahli. Dari berbagai saran yang telah diberikan oleh validator, maka peneliti melakukan revisi perbaikan. Adapun rangkuman perbaikan yang telah dilakukan peneliti dapat dilihat pada Tabel 2.

Tabel 2. Hasil Revisi Petunjuk Praktikum atas Saran Validator

\begin{tabular}{|c|c|c|}
\hline No & Masukan & $\begin{array}{l}\text { Revisi yang } \\
\text { dilakukan }\end{array}$ \\
\hline 1 & $\begin{array}{l}\text { Evaluasi diharapkan } \\
\text { mengadopsi soal-soal IPA } \\
\text { yang memiliki konsep } \\
\text { HOT'S }\end{array}$ & $\begin{array}{l}\text { Memperbaiki } \\
\text { soal no. } 2 \\
\text { pada fase } \\
\text { exploration } \\
\text { dan soal no. } 1 \\
\text { pada fase } \\
\text { evaluation }\end{array}$ \\
\hline 2 & $\begin{array}{l}\text { Perhatikan penggunaan } \\
\text { istilah kalor dan panas }\end{array}$ & Diperbaiki \\
\hline 3 & $\begin{array}{l}\text { Pada halaman ketiga istilah } \\
\text { titik cair diganti dengan } \\
\text { titik lebur (konsistensi) }\end{array}$ & Diperbaiki \\
\hline 4 & $\begin{array}{l}\text { Keterampilan berhipotesis } \\
\text { pada hal. Empat diganti } \\
\text { dengan "Apa yang akan } \\
\text { terjadi ketika ada kalor } \\
\text { ditambahkan pada suatu } \\
\text { zat secara terus-menerus?" }\end{array}$ & Diperbaiki \\
\hline 5 & $\begin{array}{l}\text { Gambar pada cover diganti } \\
\text { karena bersifat ambigu }\end{array}$ & $\begin{array}{l}\text { Cover } \\
\text { diganti }\end{array}$ \\
\hline 6 & Istilah asing dicetak miring & Diperbaiki \\
\hline 7 & $\begin{array}{l}\text { Perbaiki beberapa kata } \\
\text { dengan huruf kebalik-balik }\end{array}$ & Diperbaiki \\
\hline 8 & $\begin{array}{l}\text { Cari alamat sumber web } \\
\text { yang tepat pada gambar }\end{array}$ & Diperbaiki \\
\hline 9 & $\begin{array}{l}\text { Gambar air dalam gelas } \\
\text { erlenmeyer terlalu sedikit } \\
\text { sehingga tidak teramati } \\
\text { gerakan airnya ketika } \\
\text { mendidih }\end{array}$ & $\begin{array}{l}\text { Gambar } \\
\text { sudah diganti }\end{array}$ \\
\hline 10 & $\begin{array}{l}\text { Soal no. } 2 \text { pada fase } \\
\text { exploration yang kedua } \\
\text { dibuang atau diganti } \\
\text { karena membahayakan }\end{array}$ & Soal dibuang \\
\hline 11 & $\begin{array}{l}\text { Soal evaluation pada hal. } 7 \\
\text { no. } 2 \text { "dipinggiran" diubah } \\
\text { karena "di pinggiran" (ada } \\
\text { spasi) }\end{array}$ & Diperbaiki \\
\hline
\end{tabular}




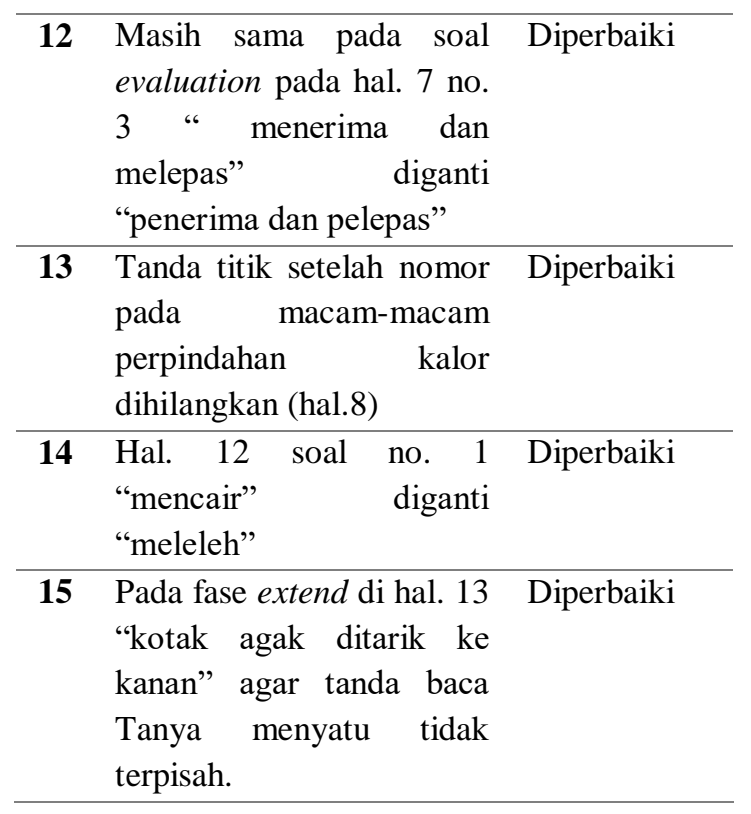

\section{Hasil Tahap Peragaan (Demonstrate Phase)}

Hasil Pengamatan Keterampilan Proses Sains (KPS) Mahasiswa

Data keterampilan proses sains mahasiswa diperoleh dari pengamatan terhadap indikator keterampilan proses sains mahasiswa setiap pelaksanaan praktikum di laboratorium. Masing-masing indikator memiliki rentang skor 1-4. Tinggi skor yang diperoleh mahasiswa diklasifikasikan menjadi 4 kriteria yaitu sangat baik, baik, sedang dan kurang. Data hasil analisis keterampilan proses sains mahasiswa oleh dua orang pengamat pada uji coba skala kecil secara rinci dapat dilihat pada Tabel 3.

Tabel 3. Keterampilan Proses Sains MahasiswaSkala Kecil

\begin{tabular}{ccccc}
\hline $\begin{array}{c}\text { Jumlah } \\
\text { Mahasis } \\
\text { wa }\end{array}$ & $\begin{array}{c}\text { Skor } \\
\text { Ter- } \\
\text { tinggi }\end{array}$ & $\begin{array}{c}\text { Skor } \\
\text { Terend } \\
\text { ah }\end{array}$ & $\begin{array}{c}\text { Rata- } \\
\text { rata }\end{array}$ & $\begin{array}{c}\text { Kate } \\
\text { gori }\end{array}$ \\
\hline 6 & 20,8 & 15,8 & 18,1 & Baik
\end{tabular}

Pada penilaian keterampilan proses sains mahasiswa, selain dilakukan analisis deskriptif juga dilakukan analisis pada tiap-tiap aspek keterampilan proses sains. Data hasil analisis tiap-tiap aspek keterampilan proses sains di laboratorium pada pertemuan pertama dapat dilihat pada Tabel 4.
Tabel 4.Rata-Rata Nilai Tiap Aspek Keterampilan Proses Sains Skala Kecil pada pertemuan pertama.

\begin{tabular}{llcc}
\hline No & Aspek & $\begin{array}{c}\text { Skor Rata- } \\
\text { rata }\end{array}$ & $\begin{array}{c}\text { Katego } \\
\text { ri }\end{array}$ \\
\hline 1. & $\begin{array}{l}\text { Mengajukan } \\
\text { pertanyaan }\end{array}$ & 18,0 & Baik \\
2. & $\begin{array}{l}\text { Berhipotesis } \\
\text { Merencanakan }\end{array}$ & 14,0 & $\begin{array}{c}\text { Sedang } \\
\text { 3. }\end{array}$ \\
& percobaan & & Sedang \\
4. & Melakukan & 18,5 & Baik \\
& percobaan & & \\
5. & Interpretasi & 16,5 & Baik \\
6. & Berkomunikasi & 19,5 & Baik \\
\hline
\end{tabular}

Sedangkan untuk data hasil analisis tiap-tiap aspek keterampilan proses sains di laboratorium pada pertemuan kedua dapat dilihat pada Tabel 5 .

Tabel 5. Rata-Rata Nilai Tiap Aspek Keterampilan Proses Sains Skala Kecil pada pertemuan kedua

\begin{tabular}{llcc}
\hline No & Aspek & $\begin{array}{c}\text { Skor Rata- } \\
\text { rata }\end{array}$ & Kategori \\
\hline 1. & Mengajukan & 20,5 & $\begin{array}{c}\text { Sangat } \\
\text { Baik }\end{array}$ \\
& pertanyaan & & Baik \\
2. & Berhipotesis & 17,0 & Baik \\
3. & Merencanakan & 17,5 & \\
& percobaan & & Sangat \\
4. & Melakukan & 21,5 & Baik \\
& percobaan & & Baik \\
5. & Interpretasi & 17,5 & Sangat \\
6. & Berkomunikasi & 22,0 & Baik \\
\hline
\end{tabular}

Berdasarkan data di atas dapat disimpulkan bahwa rata-rata hampir semua aspek keterampilan proses sains mahasiswa pada pertemuan pertama ke pertemuan kedua mengalami peningkatan. Dari kategori baik meningkat menjadi kategori sangat baik dan kategori sedang meningkat menjadi kategori baik.Adapun apek Interpretasi baik pertemuan pertama dan kedua sudah masuk pada kategori baik.

\section{Hasil Peningkatan Keterampilan Proses Sains Mahasiswa}

Data utama yang dipakai untuk melihat peningkatan keterampilan proses sains mahasiswa adalah data hasil pretest dan postest pada awal dan akhir pertemuan dengan lima 
indikator keterampilan proses sains. Indikator tersebut meliputi mengajukan pertanyaan, berhipotesis, merencanakan percobaan, menerapkan konsep dan berkomunikasi. Perhitungan nilai keterampilan proses sains mahasiswa pada uji coba skala kecil dapat dilihat pada Tabel 6 .

Tabel 6. Hasil Peningkatan Keterampilan Proses Sains Mahasiswa Skala Kecil

\begin{tabular}{ccccc}
\hline $\begin{array}{c}\text { Jumlah } \\
\text { Mahasis } \\
\text { wa }\end{array}$ & $\begin{array}{c}\text { Rata- } \\
\text { rata } \\
\text { Pretest }\end{array}$ & $\begin{array}{c}\text { Rata- } \\
\text { rata } \\
\text { Postest }\end{array}$ & $\begin{array}{c}\text { N- } \\
\text { gain }\end{array}$ & $\begin{array}{c}\text { Kate } \\
\text { gori }\end{array}$ \\
\hline 6 & 41,33 & 76 & 0,6 & $\begin{array}{c}\text { Se- } \\
\text { dang }\end{array}$ \\
\hline
\end{tabular}

Dari hasil Tabel di atas, dapat disimpulkan bahwa penggunaan petunjuk praktikum IPA Fisika-Kimia berbasis learning cycle $5 E$ sudah mampu meningkatkan keterampilan proses sains mahasiswa dengan kategori sedang dengan nilai $\mathrm{N}$-gain 0,60 .

\section{Hasil Tahap Pengembangan (Develop Phase)}

Hasil uji coba pada kelompok kecil atau tahap sebelumnya dievaluasi dan direvisi kembali berdasarkan saran atau masukan baik dari mahasiswa maupun dari pengamat untuk menentukan pemecahan mana yang memuaskan dan yang masih perlu dikembangkan. Revisi petunjuk praktikum yang dilakukan setelah uji coba kecil dapat dilihat pada Tabel 7.

\begin{tabular}{|c|c|c|}
\hline No & Masukan & $\begin{array}{c}\text { Revisi yang } \\
\text { dilakukan }\end{array}$ \\
\hline 1. & $\begin{array}{l}\text { Termometer tidak } \\
\text { bisa mencapai suhu } \\
\text { dibawah } 0 \mathrm{C} \text { ketika } \\
\text { mengukur suhu es } \\
\text { batu. Termometer } \\
\text { beli baru atau } \\
\text { pengukuran es batu } \\
\text { di dalam termos }\end{array}$ & $\begin{array}{l}\text { Pengukuran es } \\
\text { batu di dalam } \\
\text { termos }\end{array}$ \\
\hline 2. & $\begin{array}{l}\text { Spirtus sedikit/ } \\
\text { kurang }\end{array}$ & $\begin{array}{l}\text { Peneliti membeli } \\
\text { spirtus }\end{array}$ \\
\hline 3. & $\begin{array}{l}\text { Termometer } \\
\text { kurang, banyak } \\
\text { yang rusak }\end{array}$ & $\begin{array}{l}\text { Peneliti membeli } \\
\text { termometer }\end{array}$ \\
\hline
\end{tabular}

\begin{tabular}{|c|c|c|}
\hline 4. & $\begin{array}{l}\text { Pemanasan air lama, } \\
\text { waktu kurang }\end{array}$ & $\begin{array}{l}\text { Mengganti sumbu } \\
\text { pembakar spirtus }\end{array}$ \\
\hline 5. & Suhu naik turun & $\begin{array}{l}\text { Api harus dijaga } \\
\text { tetap menyala } \\
\text { maksimal }\end{array}$ \\
\hline
\end{tabular}

\section{Hasil Tahap Penyajian (Deliver Phase)}

Tahap penyajian atau kegiatan uji coba luas dilakukan untuk melihat sejauh mana keefektifan petunjuk praktikum (prototipe 2) yang sudah divalidasi dan direvisi dalam proses pembelajaran di kelas. Pada fase ini juga dilakukan proses pengambilan data untuk mengukur keterampilan proses sains mahasiswa pada saaat praktikum, ada tidaknya peningkatan skor keterampilan proses sains dan respon mahasiswa terhadap penggunaan petunjuk praktikum IPA Fisika-Kimia berbasis learning cycle $5 E$.

\section{Hasil Pengamatan Keterampilan proses sains mahasiswa}

Pengamatan keterampilan proses sains mahasiswa pada uji coba skala luas dilakukan dengan cara yang sama pada uji coba skala kecil. Lembar keterampilan proses sains yang digunakan pada skala luas juga sama. Adapun data hasil analisis keterampilan proses sains mahasiswa oleh dua orang pengamat dengan 20 mahasiswa yang terbagi dalam enam kelompok pada uji coba skala luas secara rinci dapat dilihat pada Tabel 8.

Tabel 8. Hasil Peningkatan Keterampilan Proses

\begin{tabular}{|c|c|c|c|c|}
\hline \\
\hline $\begin{array}{c}\text { Jumlah } \\
\text { Maha- } \\
\text { siswa }\end{array}$ & $\begin{array}{l}\text { Skor } \\
\text { Ter- } \\
\text { tinggi }\end{array}$ & $\begin{array}{l}\text { Skor } \\
\text { Te- } \\
\text { rendah }\end{array}$ & $\begin{array}{c}\text { Rata- } \\
\text { rata }\end{array}$ & $\begin{array}{l}\text { Kate } \\
\text { gori }\end{array}$ \\
\hline 20 & 22,0 & 14,5 & 16,9 & Baik \\
\hline
\end{tabular}

Pada penilaian keterampilan proses sains mahasiswa, selain dilakukan analisis deskriptif juga dilakukan analisis pada tiap-tiap aspek keterampilan proses sains. Data hasil analisis tiap-tiap aspek keterampilan proses sains di laboratorium pada pertemuan pertama dapat dilihat pada Tabel 9. 
Tabel 9. Rata-Rata Nilai Tiap Aspek Keterampilan Proses Sains Skala Besar pada pertemuan pertama.

\begin{tabular}{llcc}
\hline No & Aspek & $\begin{array}{c}\text { Skor } \\
\text { Rata-rata }\end{array}$ & Kategori \\
\hline 1. & $\begin{array}{l}\text { Mengajukan } \\
\text { pertanyaan }\end{array}$ & 57,5 & Baik \\
2. & Berhipotesis & 53,5 & Baik \\
3. & $\begin{array}{l}\text { Merencanakan } \\
\text { percobaan }\end{array}$ & 54,5 & Baik \\
4. & Melakukan & 64,5 & Baik \\
& percobaan & & \\
5. & Interpretasi & 56,5 & Baik \\
6. & Berkomunikasi & 64,0 & Baik \\
\hline
\end{tabular}

Sedangkan untuk data hasil analisis tiap-tiap aspek keterampilan proses sains di laboratorium pada pertemuan kedua dapat dilihat pada Tabel 10.

Tabel 10. Rata-Rata Nilai Tiap Aspek Keterampilan

\begin{tabular}{|c|c|c|c|}
\hline No & Aspek & $\begin{array}{l}\text { Skor } \\
\text { Rata- } \\
\text { rata }\end{array}$ & Kategori \\
\hline 1. & $\begin{array}{l}\text { Mengajukan } \\
\text { pertanyaan }\end{array}$ & 70,0 & Sangat Baik \\
\hline 2. & Berhipotesis & 63,0 & Baik \\
\hline 3. & $\begin{array}{l}\text { Merencanakan } \\
\text { percobaan }\end{array}$ & 62,5 & Baik \\
\hline 4. & $\begin{array}{l}\text { Melakukan } \\
\text { percobaan }\end{array}$ & 69,0 & Sangat Baik \\
\hline 5. & Interpretasi & 66,5 & Sangat Baik \\
\hline 6. & Berkomunikasi & 71,0 & Sangat Baik \\
\hline
\end{tabular}

Berdasarkan data di atas dapat disimpulkan bahwa rata-rata semua aspek keterampilan proses sains mahasiswa pada pertemuan pertama ke pertemuan kedua mengalami peningkatan. Dari kategori baik meningkat menjadi kategori sangat baik.

Hasil Peningkatan Keterampilan proses sains Mahasiswa

Penelitian dilakukan pada satu kelas yaitu kelas 4A-(2) dengan melihat nilai pretest dan postest kemudian dianalisis dengan rumus $\mathrm{N}-$ Gain yang bertujuan untuk mengetahui apakah ada peningkatan keterampilan proses sains mahasiswa setelah menggunakan buku petunjuk praktikum IPA Fisika-Kimia berbasis learning cycle 5E. Berikut penyajian data pretest dan postest yang didapat dari mahasiswa pada uji skala besar untuk mengetahui peningkatan keterampilan proses sains sebelum dan sesudah menggunakan produk. Daftar nilai keterampilan proses sains mahasiswa pada uji coba skala luas dapat dilihat pada Tabel 11.

Tabel 11. Hasil Nilai Keterampilan proses sains Mahasiswa Skala Besar

\begin{tabular}{rrrrr}
\hline $\begin{array}{l}\text { Jumlah } \\
\begin{array}{l}\text { Maha- } \\
\text { siswa }\end{array}\end{array}$ & $\begin{array}{c}\text { Rata- } \\
\text { rata } \\
\text { Pre-test }\end{array}$ & $\begin{array}{l}\text { Rata- } \\
\text { rata } \\
\text { Postest }\end{array}$ & $\begin{array}{l}\text { N- } \\
\text { gain }\end{array}$ & $\begin{array}{l}\text { Ka- } \\
\text { tegor } \\
\text { i }\end{array}$ \\
\hline 20 & 34 & 67,1 & 0,51 & $\begin{array}{l}\text { Se- } \\
\text { dang }\end{array}$ \\
\hline
\end{tabular}

\section{Hasil Respon Mahasiswa}

Pada penilaian respon mahasiswa dengan menggunakan angket, ada enam aspek diantaranya sebagai berikut: 1) Kemudahan dalam memahami petunjuk praktikum, 2) Ketertarikan terhadap petunjuk praktikum, 3) Tambahan informasi dalam petunjuk praktikum, 4) Penguasaan konsep materi, 5) Keaktifan, dan 6) Keterlaksanaan fase-fase learning cycle $5 E$. Fungsi pemberian angket ini untuk mengetahui tanggapan mahasiswa setelah menggunakan petunjuk praktikum learning cycle $5 E$. Adapun rata-rata nilai untuk tiap-tiap aspek respon mahasiswa selengkapnya pada Tabel 12.

Tabel 12. Analisis Respon Mahasiswa terhadap Penggunaan Petunjuk Praktikum IPA Fisika-Kimia Berbasis Learning Cycle 5E

\begin{tabular}{clc}
\hline Jumlah Mahasiswa & $\begin{array}{l}\text { Rata- } \\
\text { rata Skor }\end{array}$ & Kriteria \\
\hline 20 & 26,6 & $\begin{array}{c}\text { Sangat } \\
\text { Baik }\end{array}$ \\
\hline
\end{tabular}

\section{Pembahasan}

Proses pembelajaran sains khususnya praktikum menuntut adanya keterampilan proses sains. Pada penelitian ini keterampilan proses sains mahasiswa diobservasi pada saat mahasiswa melakukan kegiatan praktikum di laboratorium dan diakhir pertemuan dengan memberikan soal essay atau uraian kemudian dilakukan analisis nilai $\mathrm{N}-\mathrm{Gain}$ antara nilai pretest dan postest tentunya dengan mengacu 
pada indikator-indikator keterampilan proses sains guna mengetahui ada tidaknya peningkatan keterampialn proses sains sebelum dan setelah perlakuan. Rangkaian aktivitas keterampilan proses sains yang dilakukan mahasiswa pada saat praktikum memberikan kategori baik. Kegiatan praktikum pada pertemuan pertama menunjukkan keterampilan proses sains yang lebih rendah dibanding dengan pertemuan yang kedua yaitu dengan nilai 17,53 (pertemuan pertama) dan 20,1 (pertemuan kedua). Hal ini kemungkinan mahasiswa masih merasa belum terbiasa dengan proses pembelajaran yang baru yaitu menggunakan petunjuk praktikum yang berbasis pada suatu berbasis pembelajaran yaitu learning cycle $5 E$, namun untuk pertemuan berikutnya keterampilan proses sains mahasiswa mengalami peningkatan. Tiap aspek keterampilan proses sains mahasiswa juga dianalisis, berikut akan disajikan diagram tiap aspek keterampilan proses sains pertemuan pertama dan kedua pada Gambar 2.

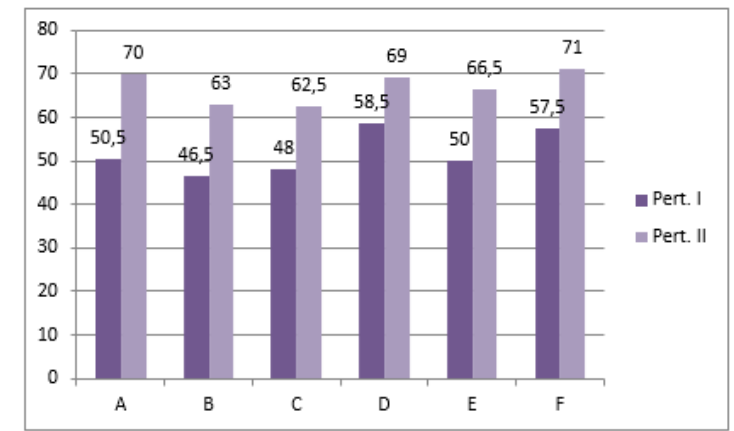

Gambar 2. Aspek keterampilan proses sains pertemuan pertama dan kedua

Keterangan indikator keterampilan proses sains:

A. Mengajukan pertanyaan

B. Mengajukan hipotesis

C. Merencanakan percobaan

D. Melakukan percobaan

E. Interpretasi

F. Berkomunikasi

Dapat dilihat pada Gambar 2 bahwa semua indikator keterampilan proses sains pertemuan kedua lebih tinggi dibanding pertemuan pertama. Hal ini mengindikasikan bahwa mahasiswa sudah mulai terbiasa dengan fase-fase pada petunjuk praktikum yang berbasis learning cycle $5 E$ dimana dalam petunjuk praktikum tersebut, mahasiswa dilatih untuk mengembangkan beberapa keterampilan proses melalui fase-fase yang terdapat pada petunjuk praktikum. Dalam fase engagement, mahasiswa dilatih untuk mengembangkan indikator keterampilan proses sains (KPS) mengajukan pertanyaan dan berhipotesis seperti: "Saat kamu menggoreng, apakah kamu meraskan panas ketika memegang bagian ujung sodet? Padahal ujung sodet yang kamu pegang tidak bersentuhan langsung dengan minyak goreng yang mendidih, melainkan ujung sodet yang lain. Mengapa hal ini bisa terjadi?..."

Pada fase exploration atau penemuan konsep materi, mahasiswa dilatih dengan merancang dan melakukan suatu percobaan serta mengamati dan melakukan interpretasi (mengubah dari bentuk satu ke bentuk yang lain seperti menyajikan data percobaan ke dalam grafik atau tabel). Setelah mendapatkan data percobaan, mahasiswa dilatih untuk mengkomunikasikan hasilnya di depan kelas. Hal ini masuk pada fase explaination. Pada fase extend atau elaboration, mahasiswa dilatih untuk dapat menerapkan konsep yang sudah dipelajarin atau ditemukan dapat dikaitkan dengan aplikasi dikehidupan sehari-hari seperti: " penggunaan kompres hangat ketika seseorang sedang demam lebih dianjurkan oleh dokter dibandingkan kompres dingin. Penempatan termometer yang tepat juga harus diperhatikan. Bagaimana hubungan termometer, kompres, dan suhu badan pada konsep melepas dan menangkap kalor". Dalam hal ini, mahasiswa diharapkan mampu mengaitkan konsep kalor tentang perubahan wujud zat dalam hal melepas dan menangkap kalor terhadap fenomena di atas. Dari fase-fase tersebut, mahasiswa telah dilatih untuk dapat menguasai beberapa keterampilan proses sains. Oleh sebab itu, maka jika fase-fase tersebut dilakukan secara terusmenerus pada suatu proses pembelajaran diharapkan penguasaan keterampilan proses mahasiswa dapat menjadi lebih baik. 
Pemberian soal-soal yang bersifat kontekstual menjadikan mahasiswa lebih aktif dan lebih banyak bertanya pada saat proses pembelajaran berlangsung tepatnya pada fase engagement dan elaboration. Akibatnya, proses pembelajaran menggunakan model pembelajaran learning cycle $5 E$ dirasakan menjadi lebih menyenangkan, lebih aktif serta meningkatkan semangat dan motivasi mahasiswa selama proses pembelajaran. Hal ini sesuai dengan teori yang dikemukakan oleh Suciati dalam Mardhiyah (2010) bahwa motivasi peserta didik akan tumbuh apabila guru/dosen menerapkan pembelajaran kontekstual dalam kegiatan pembelajaran. Kesadaran peserta didik bahwa materi yang dipelajari memiliki manfaat dalam kehidupannya akan menumbuhkan motivasi pada dirinya untuk menggali lebih dalam mengenai materi tersebut melalui aktivitas tanya jawab. Hal ini terlihat pada indikator mengajukan pertanyaan memiliki rata-rata nilai tertinggi dengan kategori sangat baik pada soal postest keterampilan proses sains (KPS) namun untuk menemukan konsep suatu materi mendapatkan rata-rata terendah diantara indicator keterampilan proses yang diteliti. Tiap aspek soal keterampilan proses sains mahasiswa juga dianalisis, berikut akan disajikan diagram tiap aspek soal keterampilan proses sains pretest dan postest pada Gambar 3 .

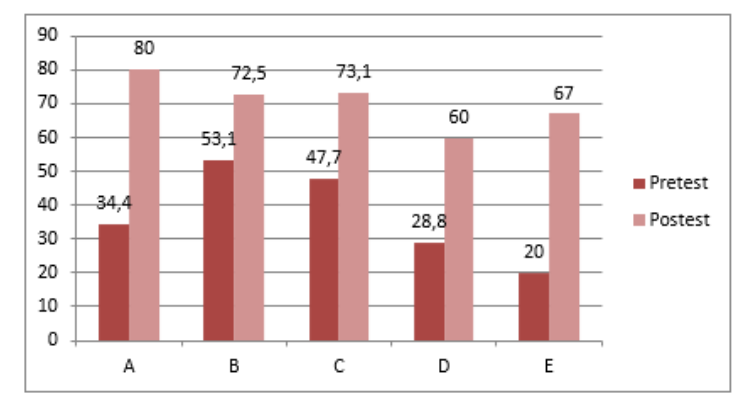

Gambar 3. Aspek soal keterampilan proses sains pretest dan postest

Keterangan indikator keterampilan proses sains:

A. Mengajukan pertanyaan

B. Mengajukan hipotesis

C. Merencanakan percobaan

D. Menerapkan konsep

E. Berkomunikasi
Dapat dilihat pada Gambar 3 bahwa semua indikator soal keterampilan proses sains postest lebih baik dari pada pretest. Seluruh rangkaian dalam pembelajaran menggunakan petunjuk praktikum berbasis learning cycle $5 E$ menyebabkan nilai $\mathrm{N}-G a i n$ antara nilai postest dan pretest dari 20 mahasiswa adalah sedang dengan rincian 4 mahasiswa memenuhi kategori tinggi, 15 mahasiswa memenuhi kategori sedang dan 1 mahasiswa memenuhi kategori rendah. Hasil akhir rata-rata nilai postest $(67,10)$ lebih baik daripada pretest $(34,00)$ dengan nilai $\mathrm{N}$-Gain 0,51 memenuhi kategori sedang.Peningkatan keterampilan proses sains mahasiswa belum menunjukkan kenaikan yang signifikan, hal ini dikarenakan mahasiswa belum maksimal dalam menjawab soal khususnya dalam indikator ketermpilan proses sains menerapkan konsep materi dengan kehidupan sehari-hari. Mahasiswa belum dapat mengaitkannya secara tepat.Indikator KPS berkomunikasi juga masih kurang, dimana mahasiswa masih kesulitan dalam membaca sebuah grafik ataupun sebaliknya.Padahal di dalam learning cycle $5 E$ sudah ada fase explaination untuk melatih mahasiswa agar berani mengutarakan pendapat atau hasil diskusi di depan kelas dan elaboration bertujuan untuk melatih mahasiswa agar dapat mengaitkan konsep materi dengan kehidupan sehari-hari (aplikasi konsep). Namun ternyata kedua fase tersebut belum dapat memberikan aspek yang maksimal terhadap penguasaaan keterampilan proses sains mahasiswa. Sehingga perlu adanya evaluasi dan penelitian lanjutan terhadap temuan tersebut.Meskipun masih terdapat 1 mahasiswa yang memenuhi kriteria rendah namun bisa disimpulkan bahwa setelah penggunaan petunjuk praktikum IPA FisikaKimia berbasis learning cycle $5 E$ dapat meningkatkan keterampilan proses sains mahasiswa.

Berdasarkan lembar angket respon mahasiswa terhadap petunjuk praktikum yang digunakan, mahasiswa memberikan tanggapan sangat positif yaitu sangat baik dengan rata-rata skor 26,6. Hasil analisis telah diperoleh 9 
mahasiswa dari 20 mahasiswa memberikan tanggapan baik dan 12 siswa dari 20 mahasiswa memberikan tanggapan sangat baik terhadap penggunaan perangkat pembelajaran learning cycle 5E. Beberapa mahasiswa mengungkapkan bahwa petunjuk praktikum berbasis learning cycle $5 E$ mengajak mahasiswa untuk selalu aktif menemukan suatu konsep, mahasiswa dapat bertukar pendapat dengan mahasiswa yang lain dan saling bekerjasama.

\section{Simpulan}

Simpulan dari penelitian ini adalah Petunjuk praktikum IPA Fisika-Kimia yang dikembangkan memenuhi kriteria sangat valid. Petunjuk praktikum IPA Fisika-Kimia yang dikembangkan dapat meningkatkan keterampilan proses sains calon guru MI/SD dengan nilai $\mathrm{N}$-gain sebesar 0,51 dengan kategori sedang. Respon mahasiswa terhadap petunjuk praktikum IPA Fisika-Kimia yang dikembangkan adalah sangat baik dengan rerata skor 26,6.

\section{Saran}

Saran bagi peneliti selanjutnya atau lembaga pendidikan: Petunjuk Praktikum IPA Fisika-Kimia berbasis learning cycle5E hendaknya dapat menjadi alternatif salah satu buku pegangan mahasiswa dalam melakukan praktikum mengingat respon yang sangat baik dari mahasiswa. Ketrampilan proses yang dikembangakan dapat lebih bervariasi dan kompleks. Guru atau Dosen pada saat menggunakan model learning cycle5E hendaknya benar-benar memperhatikan langkah-langkah dari model pembelajaran ini dan management waktu yang tepat.

\section{Referensi}

Adisendjaja, Yusuf Hilmi. 2009. Peranan Praktikum dalam Mengembangkan Keterampilan Proses dan Kerja Laboratorium. Makalah MGMP Biologi Kabupaten Garut
Cennamo, K. dan Kalk, D. 2005. Real world Instructional Design. Canada: Thomson and Wadsworth.

Hasret, N. \& Y. Necati. 2006. The Effectiveness of The Learning Cycle Berbasis to Increase Students "Achievement In The Physisc Laboratory. Turkish Science Education, 3(2): 49-65.

Hendri, Edi. 2010. Guru Berkualitas: Profesional dan Cerdas Emosi. Junal Saung Guru, 1(2): 1-11.

Permatasari, Indhah, dkk,. 2016. Pengembangan Modul Fisika SMA/MA Berbasis Siklus Belajar 7E (Learning Cycle 7E) Berbantuan Video Pada Materi Fluida Dinamis sebagai Upaya Meningkatkan Motivasi Belajar Siswa Kelas IX. Jurnal Inkuiri. ISSN: 2252-7893, Vol 5, No. 2, 2016 (hal: 134-142)

Rustaman, N. 2005. Strategi Belajar Mengajar Biologi. Malang: Universitas Negeri Malang.

Sapriati, Amalia. 2011. Pembelajaran IPA di $S D$. Jakarta: Universitas Terbuka.

Simatupang, D. 2008. Pembelajaran berbasis siklus belajar (Learning cycle). Jurnal kewarganegaraan, vol 10. No. 01 juni 2008.

Trianto.2013. Mendesaign Berbasis Pembelajaran Inovatif Progesif. Jakarta: Kencana.

Zulyetti, D. 2012. Pengembangan Penuntun Praktikum Biologi Berbasis Inkuiri Terbimbing untuk Kelas XI Semester 1. Tesis. Universitas Negeri Padang. 